\title{
Sistem Informasi Manajemen Proyek Video Editing Berbasis Web Menggunakan PRINCE2 Di Faia Art
}

\author{
Titus Kristanto ${ }^{1}$, Anita The resia Kurniawati ${ }^{2}$, Titus Lilia Sugita ${ }^{3}$ \\ Program Studi Rekayasa Perangkat Lunak, Institut Teknologi Telkom Surabaya ${ }^{1}$ \\ Program Studi Teknik Informatika, Institut Teknologi Adhi Tama Surabayaa, \\ $\underline{\text { tintus.chris@gmail.com }}{ }^{1}$, anitateku@yahoo.com ${ }^{2}, \underline{\text { tituslilia.tl@g mail.com }}^{3}$
}

Diterima: 9 Mei 2019. Dis etujui 10 Mei 2019. Dipublikasikan 27 Mei 2019

\begin{abstract}
Abstrak - Faia Art merupakan perusahan di bidang fotografi dan videografi. Faia Art memiliki kru yang sangat profesional di bidang wedding moments. Selama kegiatan proyek wedding moments, Faia Art membutuhkan manajemen proyek yang tepat dan benar dalam mengelola proyek dari awal hingga akhir proyek. Selama ini manajemen proyek yang dilakukan Faia Art masih manual, menyebabkan kurang efisien dari segi biaya, waktu, sumber daya, sehingga diperlukan aplikasi manajemen proyek video editing menggunakan metode PRINCE2. Berdasarkan hasil pengujian dengan metode PRINCE2 dapat membantu dan memudahkan user dalam melakukan manajemen proyek video editing.
\end{abstract}

Kata Kunci :Faia Art, Manajemen Proyek, PRINCE2, Video Editing

\section{PendahuluaN}

Faia Art merupakan perusahaan yang bergerak di bidang fotografi dan videografi. Faia Art mempunyai kru yang sangat profesional di bidang kegiatan wedding moments. Arti dari bidang wedding moments adalah bidang yang menangani serangkaian prosesi pernikahan, mu lai dari lamaran, ijab kabul dan resepsi pernikahan. Demi lancarnya sebuah proyek prosesi pernikahan dibutuhkan manajemen yang tepat dan benar untuk mengelola proyek dari awal hingga akhir berupa manajemen proyek.

Perkembangan manajemen proyek dimulai dari bagaimana cara mengkoordinasikan berbagai bagian dari pekerjaan secara menyeluruh dan kompleks sehingga dapat mempercepat proyek selesai[1]. Pada manajemen proyek, mempunyai waktu kerja yang dibatasi dengan jadwal yang sudah ditentukan[2]. Perubahan kondisi di lapangan sangat cepat, sehingga pimpinan proyek menyusun tindakan yang diperlukan di lapangan. Sehingga diperlukan konsep perencanaan yang sangat matang berdasarkan data, informasi, kemampuan, dan pengalaman [3].
Kegiatan video editing adalah suatu kegiatan untuk memilih atau menyunting beberapa gambar dari hasil shooting dengan cara memotong gambar ke gambar (cut to cut)[4]. Ibarat video editing merupakan gabungan dari beberapa gambar-gambar dengan cara menyisipkan sebuah transisi[5].

Dalam pembuatan manajemen proyek, diperlukan metode yang dapat digunakan. Salah satunya adalah metode PRINCE2. PRINCE2 merupakan metode yang terstruktur dan efektif dalam pengelolaan manajemen proyek, serta menawarkan panduan praktik terbaik non-eklusif secara internasional[6]. PRINCE2 juga menyediakan berbagai prosedur untuk melakukan koordinasi sumber daya dalam merancang dan mengatur aktivitas, serta memberikan acuan apa yang harus dilakukan, bahkan membagi proyek untuk dikelola pada setiap tahapan yang dapat dikontrol[7].

\section{TINJAUAN PUSTAKA}

\section{A. Faia Art}

Faia Art Photography and Videography berdiri sejak 2013, merupakan perusahaan bergerak di bidang fotografi dan videografi. Faia Art mempunyai crew yang sangat profesional di bidang fotografi dan sudah menjalankan banyak proyek yang dikerjakan di bidang videografi dan fotografi. Faia Art mempunyai visi misi dalam meningkatkan kualitas perusahaan dan menjaga kualitas produksi.

\section{B. Video Editing}

Pembuatan film terdiri dari lebih dari satu shot, sehingga diperlukan editing yang mempunyai peranan penting dalam pembuatan film. Pada proses editing dapat melakukan manipulasi waktu dalam film, sehingga waktu yang dibuat menjadi lebih singkat atau lebih lambat. Tahap editing yang dikerjakan seorang editor mulai dari proses pengambilan gambar, pemikiran editing (editing thinking)hingga materi siap untuk diubah. 
Editing merupakan proses untuk menyambung beberapa gambar dari banyak shot menjadi satu cerita utuh [8]. Seorang editor menyusun shot menjadi sebuah scene, lalu penyusun scene disusun hingga tercipta sequence menjadi akhir dari sebuah film utuh[9].

Di dalam pengerjaan, editing terbagi menjadi

2 jenis yaitu [8]:

1) Linear Editing

Editing disusun berdasarkan gambar satu per satu secara berurutan dari awal hingga akhir. Editor wajib mengulang kembali proses editing yang telah dilakukan.

2) Non-Linear Editing

Editing disusun berdasarkan gambar secara acak (random). Editor tidak perlu mengulang dari awal, berurutan hingga akhir. Editor bisa melakukan dari akhir, awal, maupun tengah, tergantung dari materi yang telah siap terlebih dahulu.

\section{Manajemen Proyek}

Manajemen proyek merupakan pengaplikasian dari ilmu pengetahuan, keterampilan, peralatan, dan teknik untuk kegiatan proyek yang memenuhi persyaratan proyek [10]. Pengelola proyek tidak harus berusaha mengenalkan ruang lingkup yang spesifik, biaya, waktu, dan kualitas proyek, juga sebagai fasilitasi semua kebutuhan me lalui ko munikasi yang terlibat dalam proyek.

Proyek merupakan usaha dalam mengerjakan sesuatu untuk mencapai atau menyelesaikan tujuan unik[11]. Proyek melibatkan beberapa orang yang bekerja dalam aktivitas yang saling berhubungan.

\section{PRINCE2}

Aplikasi manajemen proyek dengan metodologi PRINCE2 didasarkan pada pengalaman manajer proyek profesional[12]. Keuntungan dari metodologi PRINCE2 dalam manajemen proyek dengan penekanan pada kualitas dari proyek[13].

PRINCE2 menawarkan pendekatan standar untuk manaje men proyek, umu mnya digunakan oleh pemerintah dan organisasi global. PRINCE2 mengimplementasikan manajemen proyek berdasarkan 4 pilar yaitu Prinsip, Tema, Proses, dan Adaptasi PRINCE2[13].

Prinsip merupakan elemen wajib yang menjamin manajemen proyek. Tema menunjuk pada aspek filosofi proyek, diwujudkan berdasarkan proses di awal, selama implementasi, dan akhir proyek.

Prinsip-prinsip tersebut berdasarkan pada pengalaman dari proyek-proyek sebelumnya (baik sukses maupun gagal). Jika proyek didukung oleh PRINCE2, perlu didefinisikan sebagai universal, dapat diterapkan pada proyek dan dukungan, serta menawarkan untuk beradaptasi dengan manajemen proyek dan kebutuhan. Kunci sukses pada metode PRINCE2 adalah adaptasi dan penyesuaian sesuai dengan kebutuhan proyek. Pada Gambar 1 menggambarkan 7 prinsip dari metodologi PRINCE2.

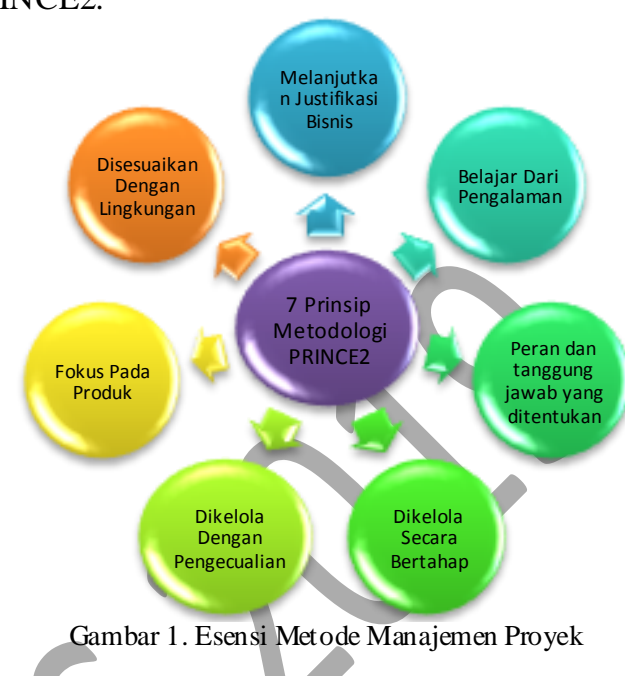

Mengelola secara bertahap memungkinkan penilaian secara berkala dari tahap akhir dan melanjutkan ke tahap berikutnya. Keuntungannya adalah dimungkinkan untuk memecah proyek menjadi beberapa potongan yang dapat dikelola. Jumlah tahapan bergantung pada ukuran proyek dan risiko yang terkait [14].

Pada Gambar 2 menggambarkan proses manajemen proyek dengan metodologi PRINCE2.

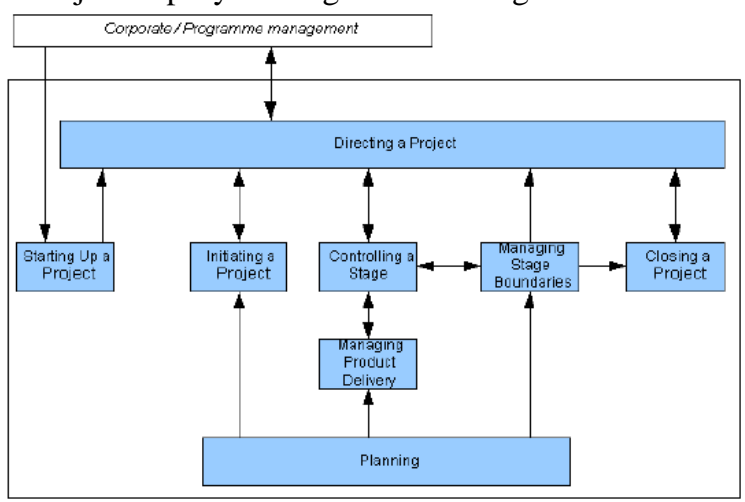

Gambar 2. Proses manajemen proyek dengan PRINCE2

Berikut tahapan proses manajemen proyek dengan metode PRINCE2 [15] :

1. Starting Up a Project (Memulai Sebuah Proyek) Membahas penyusunan suatu proyek dimulai.

2. Planning (Perencanaan)

Memulai mengidentifikasi produk dan analisis proyek

3. Initiating a Project (Menginisiasi Proyek) Memberikan perbaikan dari proyek yang dikerjakan

4. Directing a Project (Mengarahkan Proyek) Memberikan perhatian terhadap aspek controller.

5. Controliing a Stage (Mengontrol Stage) 
Mendefinisikan prosedur untuk mengendalikan atau mengontrol setiap tahapan sebelumnya yang sudah dilakukan.

6. Managing Product Delivery (Mengelola Pengiriman Produk)

Menyelesaikan aspek penerimaan, eksekusi, dan pengiriman paket kerja.

7. Managing Stage Boundaries (Mengelola Tahap Batas)

Mendefinisikan tugas-tugas yang harus ada pada setiap tahap, termasuk mendefinisikan tahapan akhir selanjutnya.

8. Closing a Project (Menutup Proyek)

Proyek secara resmi selesai dan membebaskan sumber daya proyek yang tersisa.

\section{ANALIS IS Dan PeranC ANGan Sis TEM}

\section{A. Desain Alur Kerja Sistem Dengan Metode} PRINCE2

\section{Starting Up A Project}

Pada tahap starting up a project, me mbahas awal mulai proyek video editing yang diberikan oleh ketua tim berupa file video dari cameraman yang diterima. Ketua tim memberikan tugas ke masingmasing anggota tim yang sudah mempunyai jobdesc masing-masing.

\section{Planning}

Pada tahap Planning, menentukan tema, biaya proyek, anggota tim, dan membuat jadwal pengerjaan proyek. Pada awal pengerjaan proyek, dilakukan diskusi terlebih dahulu dengan customer untuk mengetahui tema yang diinginkan dan besaran biaya tema yang sudah ditentukan sebelumnya.

Selanjutnya melakukan penjadwalan proyek video editing.Lama pengerjaan proyek tergantung dari tema yang diinginkan oleh customer dan menentukan anggota proyek.

\section{Initiating A Project}

Pada tahap Initiating A Project dilakukan hampir sama dengan tahap Starting Up A Project, hanya saja memberikan rate plus atau memperbaiki. Di tahap ini, anggota tim proyek memu lai pekerjaan yang diberikan oleh ketua tim sesuai jobdesc masing-masing.

\section{Directing A Project}

Pada tahap directing a project dilakukan kontrol awal apabila terjadi ketidakcocokan dari rencana awal maka dilakukan perubahan rencana untuk kemungkinan resiko yang terjadi selama proses video editing.

\section{Controlling A Stage}

Pada tahap controlling a stage, mendefinisikan prosedur untuk mengendalikan atau mengontrol setiap tahapan sebelumnya yang telah dilakukan pada proses video editing. Pada proses controlling untuk manajemen proyek adanya warning jika sudah mendekati dateline proyek.

\section{Managing Product Delivery}

Pada tahap managing product delivery, hasil video yang telah dilakukan proses editing dijalankan, dis ampaikan, dan diterima o leh ketua tim video editing untuk dibandingkan dengan rencana awal proyek. Ketu tim juga memeriksa hasil laporan dari anggota proyek dan apabila ada ketidakcocokan maka anggota tim harus memperbaiki hasil video editing.

\section{Managing Stage Boundaries}

Pada tahap managing stage boundaries, anggota tim me meriksa hasil video editing dari ketua tim pada tahap sebelumnya managing product delivery. Jika tidak terjadi kecocokan, maka anggota tim harus memperbaiki hasil video editing dan melakukan laporan ulang ke ketua tim hingga disetujui.

\section{Closing A Project}

Pada tahap closing a project, secara resmi mengakhiri proyek dan menyelesaikan sumber daya yang tersisa. Mengukur tingkat kesuksesan proyek dan catatan laporang produksi untuk analisis proyek pada proyek video editing berikutnya.

\section{B. Perancangan Output Menggunakan UML (Unified Modelling Language)}

Saat ini Faia Art masih melakukan proses manajemen proyek secara manual. Sehingga sistem yang dibangun diharapkan dapat membantu proses manajemen proyek pada Faia Art dan dapat diakses melalui PC desktop agar lebih mudah mengontrol proyek video editing.

Dalam perancangan aplikasi dengan metode PRINCE2, menggunakan pemodelan UML (Unified Modelling Language) antara lain :

Use Case Diagram

Pada Gambar 3 merupakan use case diagram dalam proyek video editing. 


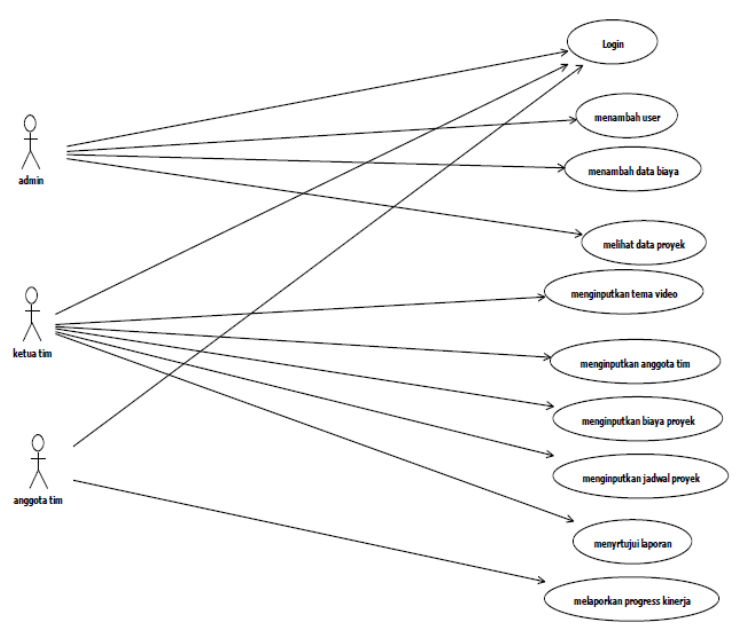

Gambar 3. Use case diagram proyek video editing

Pada Gambar 3 menjelaskan bahwa admin melakukan login ke sistem, kemudian admin menambah user, menambah biaya, dan admin dapat melihat proyek yang sudah dilaksanakan. Ketua tim video editing melakukan login ke sistem, kemudian menentukan tema dari video yang akan dilakukan proses editing.

Langkah selanjutnya, ketua tim video editing menghitung besaran biaya yang diperlukan selama proyek berlangsung, merencanakan penjadwalan proyek, dan menentukan anggota tim proyekvideo editing. Masing-masing anggota tim video editing melaporkan progress kerja kepada ketua tim.

\section{B) Activity Diagram}

Terdapat beberapa activity diagram yang dilakukan pada proyek video editing. Pada Gambar 4 menggambarkan activity diagram login user.User memasukkan username dan password, lalu melakukan autentifikasi. Jika username dan passwordbenar, maka user dapat melanjutkan tahap selanjutnya. Jika username dan password salah, maka user kembali memasukkan username dan password dengan benar.

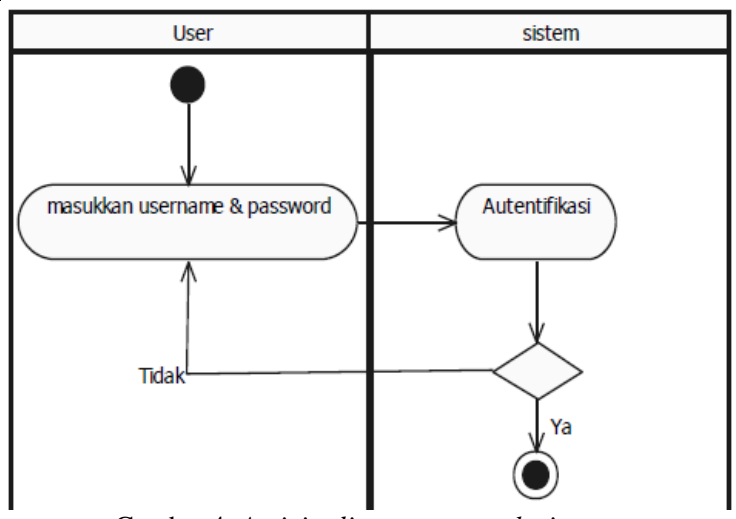

Gambar 4. Activity diagram proses login user

Pada Gambar 5 menggambarkan activity diagram tambah user.Admin memilih data user, lalu sistem menampilkan data user. Kemudian admin memasukkan data user dari proyek dan sistem menyimpan data $u s e r$.

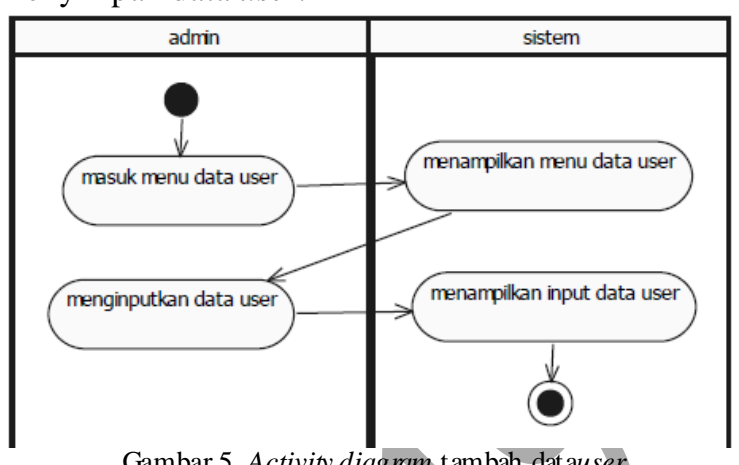

Gambar 5. Activity diagram tambah datauser

Pada Gambar 6 menampilkanactivity diagram data proyek video editing. Admin memilih menu data proyek, lalu sistem menampilkan data proyek.

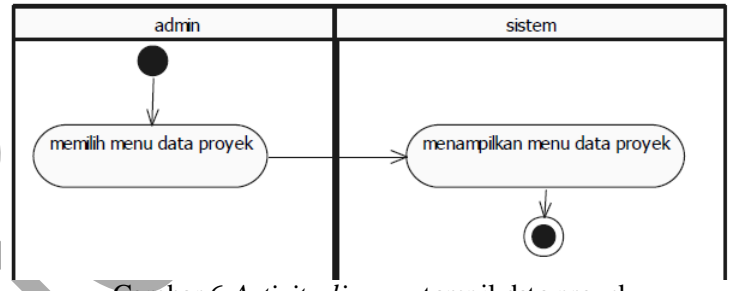

Gambar 6.Activity diagram tampil dat a proyek

Pada Gambar 7 menggambarkan activity diagram tambah tema dari proyek video editing. Ketua tim memilih menu tambah tema, lalu sistem menampilkan menu tambah tema. Kemudian ketua tim menambahkan tema video editing dari proyek dan sistem menyimpan data tema video editing.

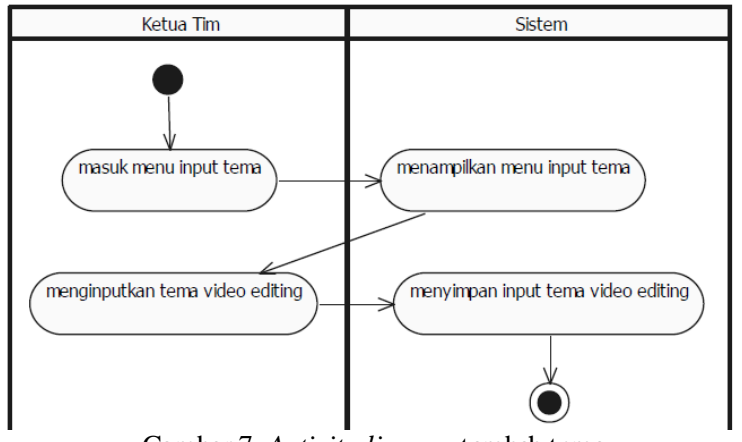

Gambar 7. Activity diagram tambah tema

Pada Gambar 8 menggambarkan activity diagram tambah biaya proyek video editing dan pada Gambar 9 menggambarkan activity diagram tambah jadwal proyek. 


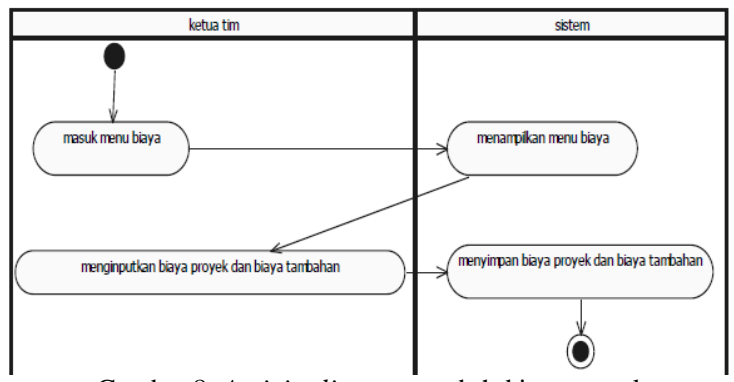

Gambar 8. Activity diagram tambah biaya proyek

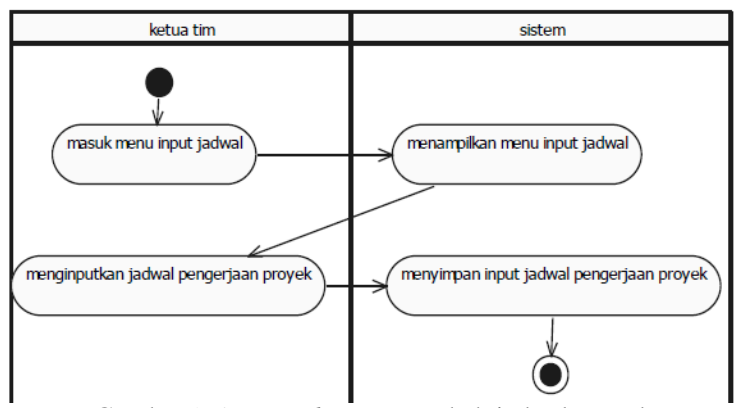

Gambar 9 Activity diagram tambah jadwal proyek

C) Sequence Diagram

Pada Gambar 10 menggambarkan sequence diagram proses login dan pada Gambar 11 mengga mbarkan sequence diagram tambah user.

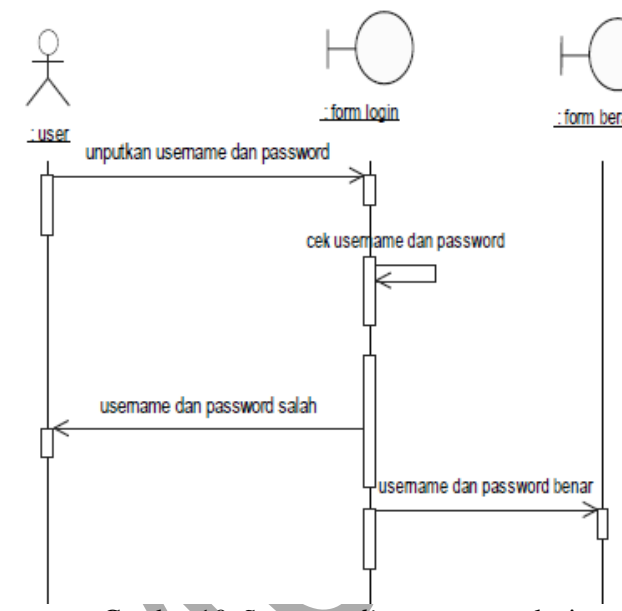

Gambar 10. Sequence diagram proses login

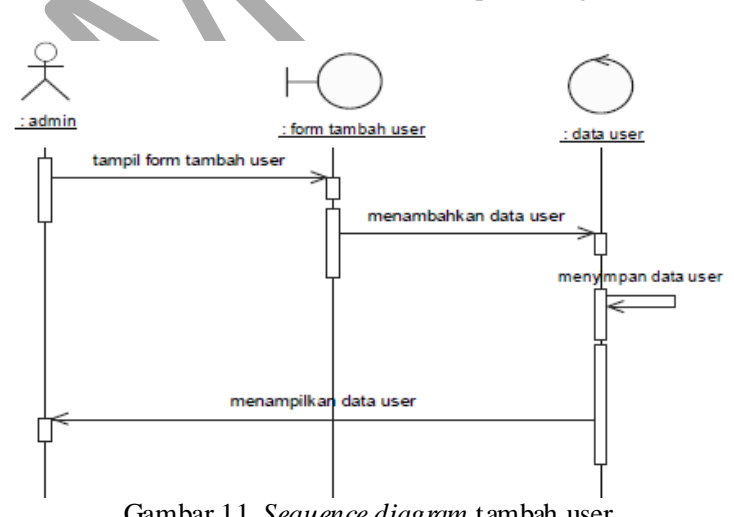

Gambar 11. Sequence diagram tambah user
Pada Gambar 12 menggambarkan sequence diagram tambah biaya dan Gambar 13 menggambarkan sequence diagram ketua tim tambah proyek video editing.
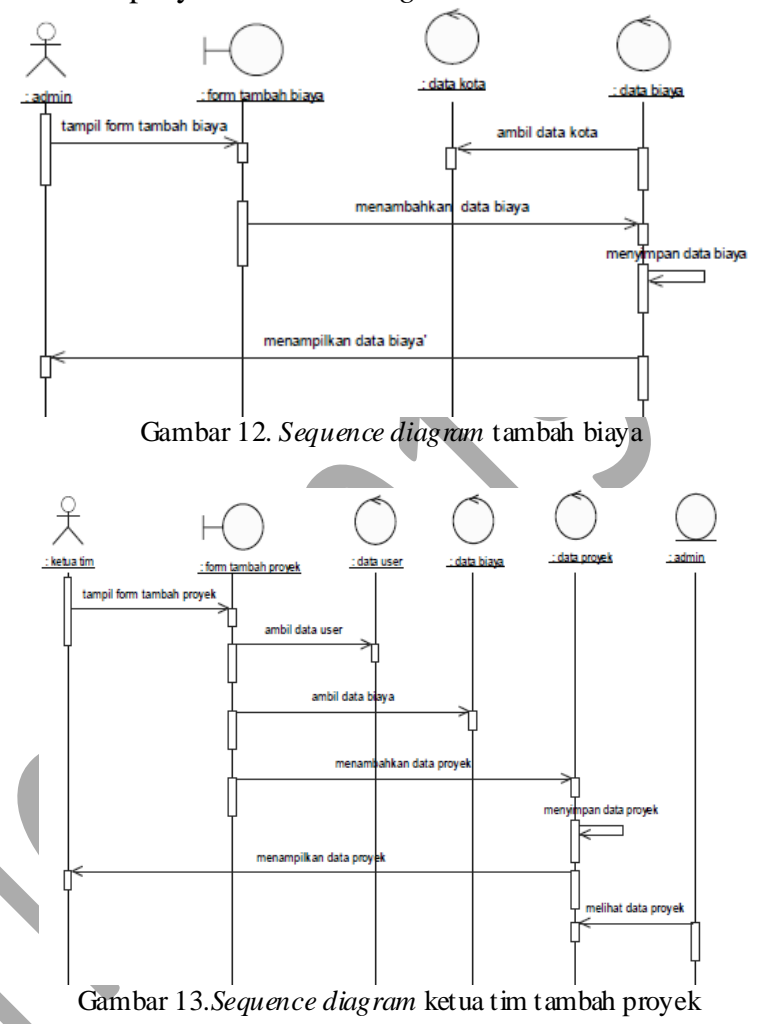

D) Class Diagram

Class diagram dari manajemen proyek video editing, dapat dilihat pada Gambar 14.

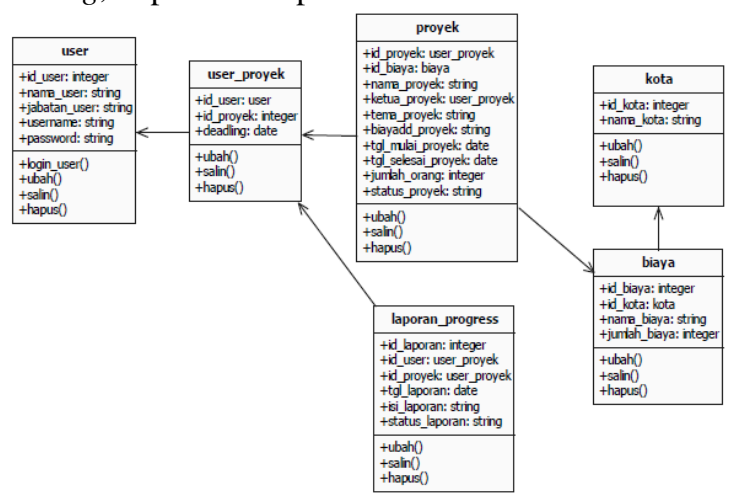

Gambar 14. Class diagram manajemen proyek video editing

Berikut penjelasan pada Gambar 14. Sebagai contoh Faia Art menerima proyek dari customer yang ingin dilakukan dokumentasi pre-wedding dengan membuat film pendek untuk ditayangkan pada saat resepsi customer. Tahap awal yang dilakukan adalah meeting dengan klien dari pertama kali yang dibicarakan sesuai dengan tema yang diinginkan oleh customer.

Customer menginginkan tema "Love at The First Sight”, dimana cerita awal pertemuan customer 
dengan pasangan. Lokasi sesuai dengan pengalaman customer. Kemudian pihak Faia Art melakukan perhitungan biaya yang menjadi dasar dalam penentuan harga untuk ditawarkan ke customer. Ketua tim menentukan jumlah orang yang akan mengerjakan proyek yaitu 4 orang terdiri dari cameraman, sinematografi, effect editor, dan audio editor.

Ketua tim membuat jadwal pengerjaan proyek film pendek dengan batas waktu 15 hari. Proyek film dimulai 2-17 April 2018. Pada Tabel 1 menunjukkan rincian jadwal pengerjaan proyek film pendek.

TABEL1 JADW AL PENGERJAAN PROYEK

\begin{tabular}{|c|c|c|c|}
\hline \multicolumn{4}{|c|}{ Jadwal Pengerjaan Proyek } \\
\hline Cameraman & Sinematografi & $\begin{array}{c}\text { Effect } \\
\text { Editor }\end{array}$ & $\begin{array}{c}\text { Audio } \\
\text { Editor }\end{array}$ \\
\hline $\begin{array}{c}\text { 2-3 April } \\
2018\end{array}$ & 4-6 April 2018 & $\begin{array}{c}7-9 \text { April } \\
2018\end{array}$ & $\begin{array}{c}10-12 \text { April } \\
2018\end{array}$ \\
\hline
\end{tabular}

Jadwal pengerjaan proyek pada Tabel 1 dibuat dengan batas maksimal dikarenakan hasil pengerjaan proyek ditunjukkan terlebih dahulu ke ketua tim.Kemudian dilakukan evaluasi bersama dengan customer. Jika ada hasil yang kurang sesuai dengan keinginan customer, maka masih ada waktu untuk me mperbaiki proyek film pendek.

\section{IMPLEMENTASI SIS TEM}

\section{A. Implementasi Metode PRINCE2 Pada} Antarmuka Sistem

1. Starting Up A Project(Memu lai Proyek)

Pada tahap ini membahas tentang proyek video editingdimulai pada user bertindak sebagai admin. Pada Gambar 15 tampilan Halaman Login dan Gambar 16 tampilan Halaman Data User pada Admin.

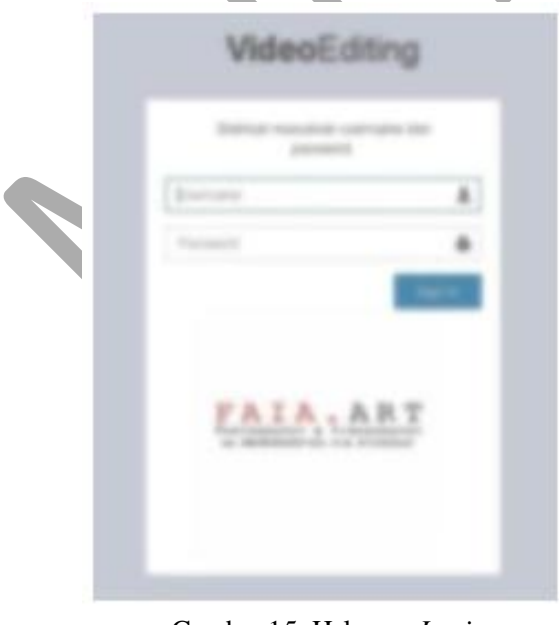

Gambar 15. Halaman Login

Pada Gambar 15 merupakan halaman login dari aplikasi manajemen proyek video editing menggunakan metode PRINCE2. Halaman Login terdapat kolom username dan password beserta tombol sign in. User harus melakukan proses login dengan memasukkan username dan password yang dimiliki oleh masing-masing user.

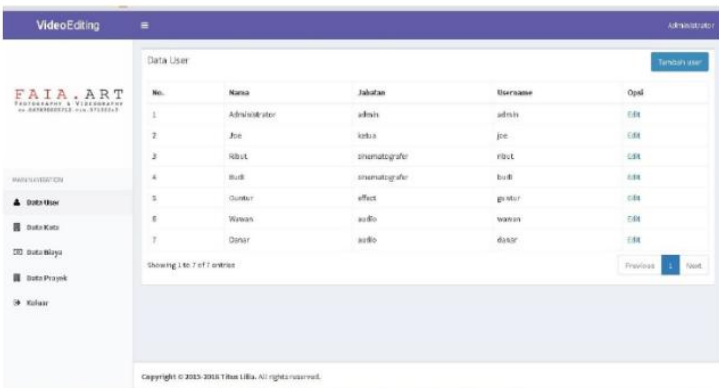

Gambar 16. Halaman Dằta UserPada Admin

Pada Gambar 16 merupakan halaman admin yang dapat melihat data semua user dan dapat menambahkan user. Di sebelah kiri terdapat pilihan menu data user, data kota, dan data proyek.

Pada Gambar 17 tampilan halaman data biaya dan pada Gambar 18 tampilan data proyek.

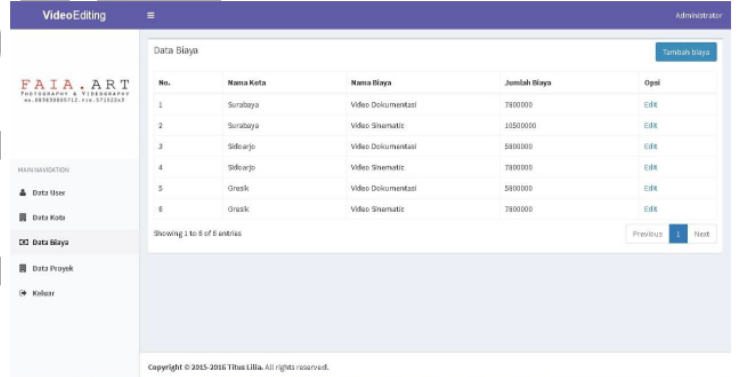

Gambar 17 Halaman data biaya

Pada halaman data biaya (Gambar 17), admin dapat melihat semua data biaya dan juga dapat menambahkan biaya. Pada halaman data proyek (Gambar 18), admn dapat melihat data semua proyek video editing yang sudah dikerjakan dan sedang dikerjakan.

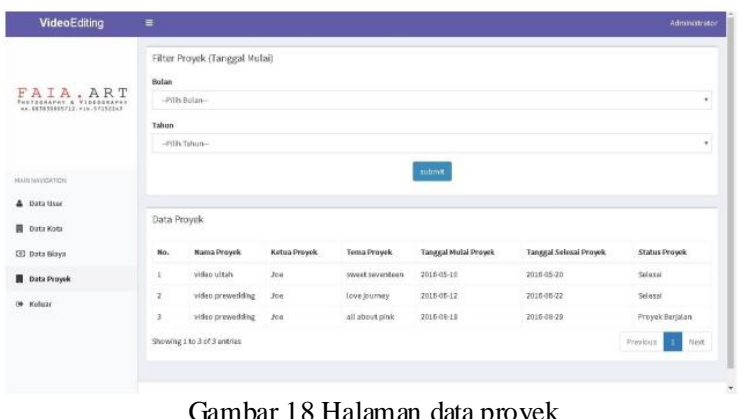

2. Planning (Perencanaan)

Ketua proyek melakukan penentuan tema, perhitungan biaya, penentuan anggota tim yang akan mengerjakan proyek, serta menentukan jadwal pengerjaan proyek. Pada Gambar 19 merupakan 
beranda dari ketua proyek video editing. Ketua proyek dapat melihat daftar proyek yang berjalan dan laporan yang harus diperhatikan dari anggota proyek. Pada daftar proyek yang sedang berjalan, terdapat beberapa menu pilihan mulai to mbol edit, detail anggota proyek beserta deadline anggota dalam pengerjaan proyek.

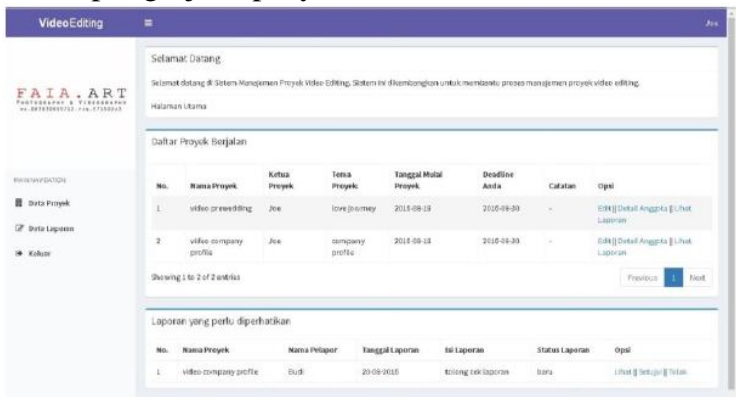

Gambar 19. Halaman beranda ketua proyek

3. Initiating A Project(Memu lai Sebuah Proyek)

Pada tahap initiating a project yang berperan adalah user sinematografi, effect editor, dan audio editor. Setelah menerima proyek dari ketua proyek, maka setiap user melakukan jobdesc-nya masingmasing dengan batas waktu yang telah ditentukan. Pada Gambar 20 merupakan halaman beranda dari sinematografi, effect editor, dan audio editor.

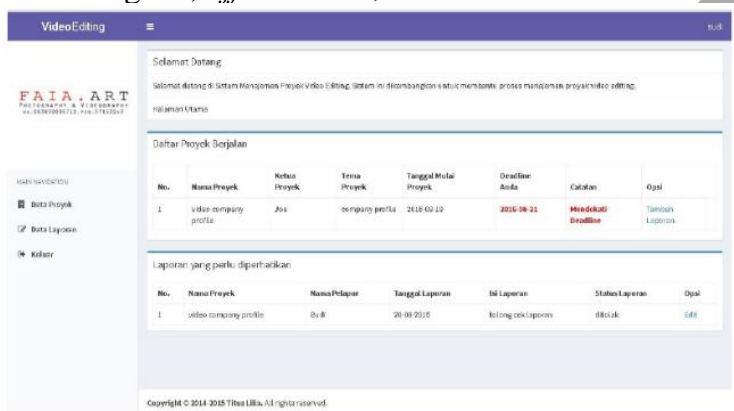

Gambar 20. Halaman beranda sinematografi, effect editor, dan

4. Directing A Project(Mengarahkan Proyek)

Pada tahap directing a project, ketua proyek melakukan kontrol awal sehingga ada ketidakcocokan dapat langsung diproses dengan melakukan perubahan rencana (reauthorized) untuk memin imalkan terjad inya resiko selama proses video editing.

5. Controlling A Stage (Mengontrol Tahapan)

Pada tahap controlling a stage berupadefinisi prosedur untuk mengendalikan atau mengontrol pada proses video editing. Pada Gambar 21 berupa warning yang muncul 2 hari sebelum deadline data proyek anggota tim proyek video editing.

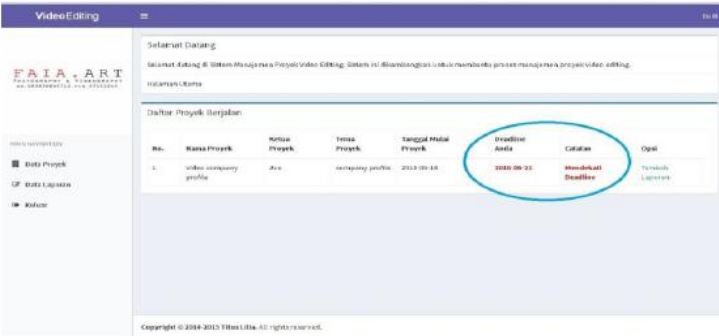

Gambar 21. Warning pada Halaman Proyek User

6. Managing Product Delivery (Mengontrol Pengiriman Hasil Produk)

Pada tahap managing product delivery, ketua proyek video editing menerima progress dari sinematografi, effect editor, dan audio editor. Ketua proyek memeriksa hasil pekerjaan dari anggota tim proyek. Jika hasil sudah sesuai maka ketua proyek dapat menyetujui laporan, tetapi jika harus diperbaiki maka anggota tim melalukan perbaikan dan laporan ulang hingga batas waktu yang sudah ditentukan. Pada Gambar 22 merupakan tampilan laporan yang disetujui.

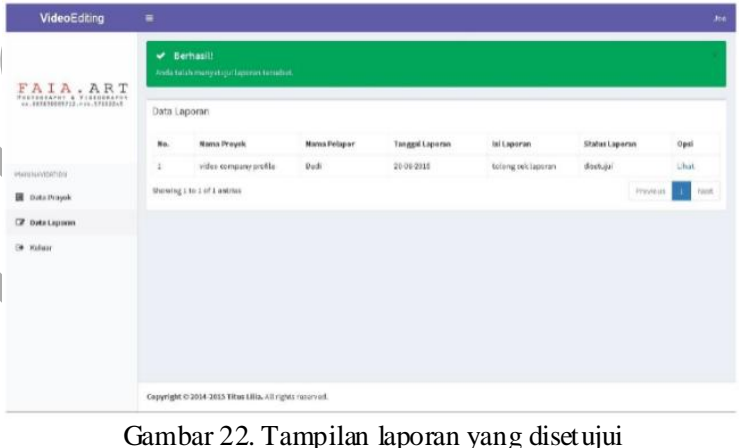

7. Managing Stage Boundaries (Mengelola Batas Tahapan)

Pada tahap managing stage boundaries, anggota tim memeriksa status laporan dari ketua proyek. Jika status laporan disetujui, maka anggota tim dapat memilih opsi selesai, seperti terlihat pada Gambar 23.

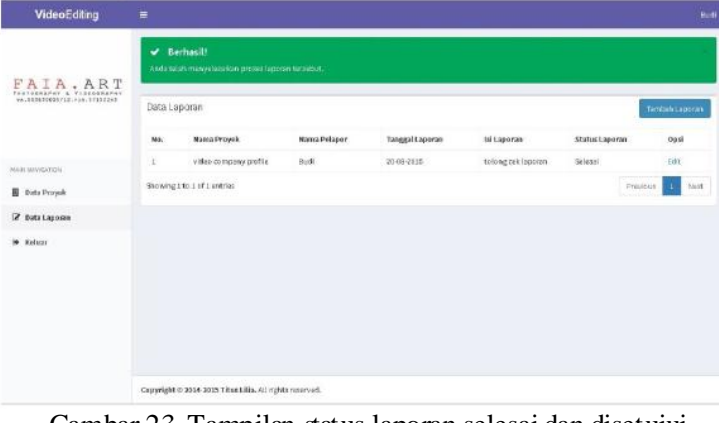

Gambar 23. Tampilan status laporan selesai dan disetujui

\section{8. $\quad$ Closing A Project (Menutup Proyek)}

Pada tahap closing a project, status proyek yang berganti dari proyek berjalan menjadi selesai 
setelah memasuki tanggal berakhirnya proyek, seperti pada Gambar 24.

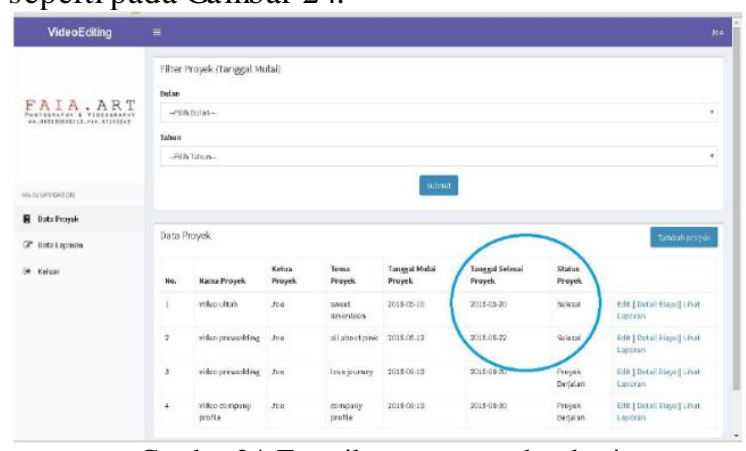

Gambar 24. Tampilan status proyek selesai

\section{B. Hasil Kuesioner}

Pada Tabel 2 merupakan tabel presentasi nilai menggunakan skala likert. Terdapat 5 item presentasi nilai, dimana memilikik batas skala menunjukkan respon alternatif.

TABEL2TABEL PRESENTASI NILAI SKALA LIKERT

\begin{tabular}{|c|c|}
\hline Presentasi Jawaban & Ke terangan \\
\hline $0 \%-19,99 \%$ & Sangat tidak setuju \\
\hline $20 \%-39,99 \%$ & Tidak Setuju \\
\hline $40 \%-59,99 \%$ & Netral \\
\hline $60 \%-79,99 \%$ & Setuju \\
\hline $80 \%-100 \%$ & Sangat Setuju \\
\hline
\end{tabular}

Berdasarkan perhitungan rata-rata awal adalah responden menilai setuju dengan presentasi sebesar 74,44\%. Secara kemudahan dalam penggunaan responden menilai presetasi sebesar $77,78 \%$. Responden menilai setuju secara aktualitas dan keandalan masing-masing presentasi sebesar $81,67 \%$ dan $72,22 \%$. Hasil rata-rata akhir menunjukan dengan jumlah 6 orang yang merupakan pegawai dari Faia Art menilai setuju dengan presentasi penilaian 76,08\%

\section{KESIMPULAN}

\section{A. Kesimpulan}

Berdasarkan hasil dari tahap analisis, perancangan, implementasi, dan uji coba dapat disimpulkan sebagai berikut :

1) Aplikasi manajemen proyek video editing menggunakan metode PRINCE2 dapat membantu dan memudahkan user untuk melakukan manajemen proyek video editing.

2) Berdasarkan hasil pengujian dengan jumlah 6 orang pegawai Faia Art, mendapatkan hasil secara informatif dengan presentasi masingmasing sebesar 74,44\%; secara kemudahan dalam penggunaan pressentasi sebesar 77,78\%; secara aktualitas dan kehandalan dengan presentasi masing-masing sebesar $81,67 \%$ dan $72,22 \%$.

\section{B. Saran}

Berdasarkan implementasi sistem yang dilakukan pada palikasi manajemen proyek video editing menggunakan metode PRINCE2, terdapat beberapa saran yaitu :

i. Perlu adanya evaluasi untuk menambah ruang lingkup data yang diolah dalam manajemen proyek video editing sesuai dengan perkembangan ilmu teknologi sehingga aplikasi bisa menjadi lebih baik dari sebelumnya.

ii. Dalam pengembangan selanjutnya, aplikasi manjemen proyek video editing diharapkan mengalami perkembangan dengan menguji dengan metode lain dan menjadikan aplikasi manaje men proyek yang lebih baik.

\section{REFER ENSI}

[1] M. I. Munir, "Evaluasi Kinerja Proyek Recondition Fire Water Pump P2226 JA Menggunakan Pendekatan Nilai Hasil di PT Taka T urbomachinery Indonesia," Universitas Widyat ama, 2012.

[2] J. P. Aris, "Sistem Informasi Manajemen Proyek Kontruksi Baja pada CV . Kumis Kontraktor," 2016.

[3] H. Hartawan, "Analisa keterlibatan manajemen proyek dalam proses perencanaan dan pengendalian proyek selama pelaksanaan konstruksi," 1993.

[4] D. W.L. Award, "Video," Univ. Dian Nuswantoro, 2013.

[5] Revva, "Story board iklan televisi Partai Karya Peduli Bangsa (PKPB) : laporan kerja praktek," Univ. Komput. Indones, 2012.

[6] S. Saad, A. Ibrahim, O. Asma, M. S. Khan, dan J. Akhtar, "A Case Study on Implementation of Prince2 Methodology in Automotive Industry in Malaysia (A Preliminary Study)," Int. J. Sci. Eng. Res., vol. 3, no. 4, hal. 1-4, 2012.

[7] R. W. Atmagi, U. L. Yuhana, dan S. Rochimah, "Rancang Bangun Perangkat Lunak Berbasis Web untuk Mengelola Proyek Menggunakan Kerangka Kerja PRINCE2," Inst. Teknol. Sepuluh Nop., hal. 1-7, 2018.

[8] D. Umbara, "Seni Editing Part 1." 2009.

[9] Ahsan, "All About Edit." 2007.

[10] Munir, Manajemen Proyek Perangkat Lunak. Bandung, 2015.

[11] A. Lawani dan D. Moore, "Project Management Practices in Government Organisations of Developing Countries: A Systematic Review," Int. J. Bus. Manag., vol. 4, no. 9, hal. 89-98, 2016.

[12] U. Şimşek dan H. Gümüşkaya, "Using PRINCE2 project management methodology to develop SOA based applications," Lecture Notes in Electrical Engineering, vol. 151 LNEE. hal. 891-902, 2013.

[13] R. Vaníčková, "Application of PRINCE2 Project Management Methodology," Stud. Commer. Bratisl., vol 10, no. 38, hal. 227-238, 2017.

[14] C. Bentley, The Essence of the PRINCE2: Project Management Method. INBOX SK, 2010.

[15] J. Dolezal, Projektovỳ management: Komplexně, prakticky a podle světovỳch standardŭ. Grada Publishing, 2016. 